\title{
Saudi EFL Teachers' Attitudes towards Professional Development
}

\author{
Maha Alzahrani \\ Technical and Vocational Training Corporation, Riyadh, Saudi Arabia \\ https://orcid.org/0000-0002-5553-2173
}

\begin{abstract}
The study reported in this paper aimed to investigate the Professional Development (PD, henceforth) needs of English language teachers in Saudi Arabia. Its primary objectives were to assess the needs of PD and training of Saudi English language teachers and to explore the teachers' attitudes towards the amount and quality of English teaching preparation received prior to their teaching career. The study adopted a mixed-method approach in order to gain a deep understanding of the phenomenon under investigation. The participants of the study included 109 Saudi teachers of English language who teach in public schools. The study involved quantitative and qualitative data collection methods. Whilst the quantitative data of the study was gathered via a survey questionnaire, the qualitative data was obtained via interviews with 10 of EFL teachers. The findings indicated the teachers' dissatisfaction with the amount and quality of pre-service training they received. This was due to poor information, a lack of qualified trainers and limited selection of topics which does not serve their teaching needs.
\end{abstract}

Keywords: English teachers; professional development; attitude; Saudi Arabia

\section{Introduction}

Professional development for Saudi English as a foreign language teachers is essential to improve teachers' competence and students' achievements. Professional development is understood as opportunities and training offered for Saudi ESL teachers to improve their knowledge, skills, language proficiency and competence, initiated by the Ministry of Education to improve teaching programs. Educators need such improvements and initiatives to influence and shape successful and proactive education. These improvements can come from an integrated and sustained system of continuous professional development, which is a powerful tool to cultivate teachers' practices and to cater to teacher and student needs. Therefore, if teachers do not have opportunities of ongoing development to enrich their knowledge and competency, they will not be actively interested and engaged in such activities that reinforce them to grow professionally in their teaching practice (DuFour \& Eaker, 1998, Igawa, 2008, 
Sparks, 2002). This aligns with Talbert and McLaughlin's (1994) illustration that "without opportunities to acquire new knowledge, to reflect on practice, and to share successes and failures with colleagues, teachers are not likely to develop a sense of professional control and responsibility" (p.130). PD provides for both experienced and novice teachers opportunities to meet their learning needs. Putnam and Borko (2000) stated if teachers want to be successful, they need opportunities to participate in a professional community that discusses new teacher materials and judicious strategies that support their practice.

\section{Statement of the problem}

The teaching of English in Saudi Arabia still does not meet satisfactory outcomes, despite the efforts of the government and Ministry of Education towards teaching and learning English as a foreign language, including modifying curricula, encouraging teachers to implement new teaching methods, etc. (Alrashidi \& Phan, 2015; Al-Seghayer, 2015; Rahman \& Alhaisoni 2013). Currently, Saudi English language teachers graduate without adequate training and competence which results in unintended outcomes as well as unsatisfactory students' achievements and proficiency (Al-Hazmi, 2003; Al-Khairy, 2013; Al-Malihi, 2015; Alrabai, 2014; Alrashidi \& Phan 2015; Al-Seghayer, 2014a; Alotaibi, 2014; Ahmad, 2014). Saudi English language teachers need more opportunities to improve their teaching practices, to improve their teaching methods and to improve subject knowledge. The lack of opportunities related to teaching English should be tackled immediately, otherwise, the constraints of teaching and learning EFL will generate counterproductive effects.

\section{Objectives of the study}

The purpose of this research was to assess the needs of professional development and training of Saudi English language teachers. This analysis required determining what professional development opportunities for English language teachers were currently available and being used in Saudi Arabia, as well as teachers' preferences for the models and durations of professional development.

\section{Research questions}

1. How do Saudi EFL teachers perceive the amount and quality of English teaching preparation they received prior to their teaching position?

2. What professional development opportunities for English teachers are available and being used in Saudi Arabia?

3. How do Saudi EFL teachers perceive the effectiveness of their professional development?

\section{Literature Review}

Professional Development for teachers is a broad term which includes a variety of aspects connected not only to a teacher's (PD) but also to his/her personal development (Igawa, 2002). Professional development is a continuous process where teachers develop their professional qualities, knowledge skills leading to the improvement of the organization and students (Craft, 1996). Continual Professional Development (CPD) is defined as: "all natural learning experiences and those conscious and planned activities which are intended to be of direct or indirect benefit to the individual, group or school, which constitute, through 
these, to the quality of education in the classroom" (Day, 1999, p. 3). PD is an important topic in language teaching which requires constant and ongoing growth of teachers' characteristics and knowledge. Teachers in teaching English as a second or foreign language need PD (Richards \& Farrell, 2005). Richards and Rodgers (2001) identified the following six essential domains of second language teacher education preparation. These include (1) theories of teaching, (2) teaching skills, (3) communication skills, (4) subject matter knowledge, (5) pedagogical reasoning and decision making and (6) contextual knowledge. Professional development is the process which seeks to adjust the attitudes and skills towards great competencies and effectiveness to meet students' needs and teachers' needs. Experience and career development via pre and in-service training would bring growth, improvements and satisfaction to teachers. Thus, they will be ready for new challenges, in current times, with organized preparation and training to develop competencies, skills and instructional practices, ultimately improving students' growth, achievement and learning.

Richard and Farrell (2005) distinguished between teacher training and teacher development, teacher training refers to short-term and immediate goals. Teacher development refers to long-term goals that attempt to facilitate teachers' growth and understanding of teaching and their existence as teachers. These scholars also identified four categories of professional development activities: they included (1) individual (self-monitoring, journal writing, teaching portfolio, action research), (2) group based (action research, case studies, support group, journal writing), (3) one- to-one (peer coaching, peer observation, team teaching, critical incidents, action research) and (4) institutional (support group, workshops, action research).

\section{Preparation of English Teachers in the KSA}

English is a fundamental prerequisite for training and employment in all public and private sectors in Saudi Arabia. Thus, teaching and learning English language are tools to enhance foreign investments in Saudi Arabia (Alrabai, 2016; Alrashidi \& Phan, 2015) as well as a priority for increasing social mobility by obtaining higher paying employment. English language teachers become qualified to teach and are awarded a Bachelor's degree in Saudi universities after completing a fouryear English major through the given programs by individual universities' English departments (Al-Hazmi, 2003; Alrashidi \& Phan, 2015; Al-Seghayer, 2014a). The first year is the preparatory year for two semesters, which is a year after graduating from secondary school. The second year begins with classes aimed at enhancing English skills such as listening, speaking, reading, writing, grammar and vocabulary. The remaining two years include classes in linguistics (phonology, syntax, applied linguistics, discourse analysis), literature (novel, drama, poetry, history of English), and translation (advanced writing and grammar) (Al-Hazmi, 2003; Alrashidi \& Phan, 2015; Al-Seghayer, 2014a).

Due to lack of program standardization within Saudi universities, the number of classes and the syllabi for English teaching preparation courses may differ from one university to another (Al-Hazmi, 2003). In most universities, students take only one course on teaching methodology, which, according to Al-Hazmi (2003) and Alrashidi and Phan (2015), is not sufficient to cater to all the needs of preservice teachers. Teaching methods courses are offered and given in the last 
semester, which are no more than three credits, representing approximately only $10 \%$ of their coursework (Al-Seghayer, 2014a). The result of this minimal training in the theory and practice of teaching English as a Foreign Language (EFL) is that universities graduate inadequately trained teachers. Thus, Al-Seghayer (2014a) stated that programs should increase the amount of English teaching preparation asserting that the "amount of time that pre-service EFL teachers spend at practicum sites needs to be further extended in length and intensity to allow extensive and intensive practical activities for student teachers... rather than waiting for last semester to do practicum" (p.147).

Al-Hazmi (2003) and Al-Malihi (2015) who pointed out that Saudi Arabian education programs are inadequate and non-systemic for the preparation of EFL teachers due to their insufficient and limited number of teaching methodology courses. Al-Seghayer (2014b) added that Saudi English language teachers lack sufficient theoretical background knowledge related to the factors influencing second language learning and acquisition. Al Malihi (2015) concurred by stating that Saudi EFL teachers are not prepared with adequate pre-service preparation nor training programs. Similarly, Alsalahi (2015) indicated that Saudi EFL teachers feel unmotivated and disempowered due to lack of PD programs. Additionally, teachers are not supported enough in in-service training programs to develop themselves professionally and to keep them updated with sufficient training. Consequently, there were be misleading and undesired effects as (Cross,1995, Crawford \& Biggs, 2008) mentioned that hiring untrained teachers in classroom results in counterproductive effects in education quality and teachers' competence.

Additionally, Oudah and Altalhab's (2018) findings revealed an optimistic view of Saudi EFL teachers towards the programs that are scheduled annually at the training centers of the Ministry of Education in Saudi Arabia. In addition, there is a need for more use of technology in educational programs that occur within the classroom as well as English language teachers are to looking forward to attending programs provided by more qualified educators and trainers and learning more about reflective skills in teaching. In the same vein, Zohairy (2012) conducted a study on the status of professional development of Saudi EFL teachers in seven universities and four private universities. The findings showed that only two universities offered EFL teachers training opportunities, and the participants were not satisfied with their professional development programs. Likewise, in Badia's (2015) study which was conducted on teacher evaluation and appraisal processes, the teachers expressed their dissatisfaction with the schemes of the teacher evaluation system as it was not enough to assess their performance appropriately.

\section{Research Methodology}

The researcher utilized a mixed-method approach consisting of quantitative measurement (an online survey) and qualitative measurement (interviews). Quantitative instrument was used, an online survey was administered, the link of the survey was sent to a random sample of 109 EFL Saudi teachers who teach in different stages (K-12) in a variety of Saudi public schools. The online survey 
focused primarily on (1) PD availability, participation, and teachers' opinions and (2) Models and Duration of PD Opportunities. With regard to the qualitative data, it was gathered via 20-minute semi-structured interviews with 10 teachers who participated in the survey and volunteered to be interviewed, whose ages ranged roughly from twenty to sixty years old.

\section{Data Analysis}

The data obtained from the participants underwent two separate sequential phases, quantitative followed by qualitative to meet the primary objectives of the current study. In regard to the quantitative data analysis, the survey was aided by the Google Forms platform that was employed to design and distribute the online survey; it automatically calculated the percentage of responses from the results. The survey instrument is the most valid and comprehensive approach (Creswell, 2012), which assisted the researcher to generalize findings with a larger population and to collect a variety of data simultaneously. Unlike the quantitative data analysis which follows a linear process, qualitative data analysis requires going back and forth between different stages, namely data exploration, thematic coding and interpretation (Creswell, 2012).

Rubin and Rubin (2005) and DiCicco-Bloom \& Crabtree (2006) pointed out that thematic coding is a logical and intuitive way of thinking and ensures that research questions are addressed. In the current study, the researcher transcribed what she recorded from each interview and then coded the salient topics and issues thematically. This included a critical reading of the interviews' transcripts to group clusters of codes and create categories to develop themes which are strongly relevant to the research questions.

\section{Results}

This section sequentially reports the results obtained from both (1) the online survey and (2) the interviews.

\section{Survey Results}

\section{PD availability, participation and opinions}

The results demonstrated that the 109 respondents' opportunities to engage in PD varied considerably. The data showed that $57 \%$ of the respondents were not provided with PD whereas the other $43 \%$ of respondents indicated that they received $\mathrm{PD}$ training. This demonstrates that majority of the teachers were not offered continuing PD.

In table 1 , the open-ended question, $57 \%$ of the respondents stated they did not receive any support or PD opportunities. Further, they concurred that there were no incentives for in-service training and no attention given to teachers' needs. However, the other $43 \%$ indicated that they were provided with PD training sessions and programs which were said to take place during one week for ten hours once a year. These findings from the survey were confirmed by teachers' interviews reported below in table 1. 
Table 1. PD Availability

1. Does your employer provide PD opportunities for English teachers?

a. If yes, briefly describe them. These include, but are not limited to, seminars, workshops, and conferences. (frequency, duration, topics)

b. If no, why do you think PD is not provided?

No. of Participants (109)

Agreed: 47 (43\%)

Disagreed $62(57 \%)$

As shown below in Table 2, 47 of the 109 respondents reported that they have participated in some form of 'PD activities' since commencing teaching English, while 62 have not participated in PD activities. The results of teacher participation in PD are like the results in Table 1 above and clearly demonstrate that approximately half of respondents have not taken part in continuing PD. Majority of teachers explained that they had not participated in PD due to the timing, place and unsatisfactory experience of repetitive topics and untrained trainers. These qualitative findings from the open-ended options on the survey were confirmed by data collected in the interviews reported below.

\section{Table 2. PD Participation}

2. Have you participated in any PD activities since you started teaching English?

a. If yes, briefly describe them. These include, but are not limited to, seminars, workshops, and conferences. (frequency, duration, topics)

b. If no, please explain why? (no opportunity, chose not to participate, no time, etc.)?

No. of Participants (109) $\quad$ Agreed: $53(49 \%) \quad$ Disagreed 56 (51\%)

In addition to the teachers' responses concerning PD availability and their participation, a five-point Likert Scale (as shown below in Table 3) was utilized to pursue responses to seven statements on the topic To what extent do you agree or disagree with the statements about your Preparedness to be an English teacher and opinions about personal development.

Table 3. Preparedness to be an English Teacher and Opinions about PD

\begin{tabular}{|c|c|c|c|c|c|}
\hline Statement & $\begin{array}{c}\text { Strongly } \\
\text { Agree }\end{array}$ & Agree & Disagree & $\begin{array}{l}\text { Strongly } \\
\text { Disagree }\end{array}$ & $\begin{array}{l}\text { Have not } \\
\text { received } \\
\text { in PD }\end{array}$ \\
\hline $\begin{array}{l}\text { 3- The university training and } \\
\text { preparation that I received before } \\
\text { beginning my first English } \\
\text { teaching position was sufficient for } \\
\text { me to be an effective English } \\
\text { teacher. }\end{array}$ & $\begin{array}{c}(17) \\
15.6 \%\end{array}$ & $\begin{array}{c}(19) \\
17.4 \%\end{array}$ & $\begin{array}{c}(39) \\
35.8 \%\end{array}$ & $\begin{array}{c}(34) \\
31.2 \%\end{array}$ & None \\
\hline $\begin{array}{l}\text { 4- PD that I have participated in } \\
\text { improved my knowledge/skills as } \\
\text { an English teacher. }\end{array}$ & $\begin{array}{c}(5) \\
4.6 \%\end{array}$ & $\begin{array}{c}(25) \\
22.9 \%\end{array}$ & $\begin{array}{c}(47) \\
43.1 \%\end{array}$ & $\begin{array}{c}(10) \\
9.2 \%\end{array}$ & $\begin{array}{c}(22) \\
20.2 \%\end{array}$ \\
\hline $\begin{array}{l}\text { 5- PD that I have participated in } \\
\text { increased the effectiveness of my } \\
\text { teaching and students' } \\
\text { performance. }\end{array}$ & $\begin{array}{r}(10) \\
9.2 \%\end{array}$ & $\begin{array}{c}(28) \\
25.7 \%\end{array}$ & $\begin{array}{c}(44) \\
40.4 \%\end{array}$ & $\begin{array}{c}(4) \\
3.7 \%\end{array}$ & $\begin{array}{c}(23) \\
21.1 \%\end{array}$ \\
\hline
\end{tabular}




\begin{tabular}{|l|c|c|c|c|c|}
\hline $\begin{array}{l}\text { 6- PD that I have participated in } \\
\text { helped me understand and utilize } \\
\text { different measurements for }\end{array}$ & $\begin{array}{c}(9) \\
\text { assessment. }\end{array}$ & $\begin{array}{c}(26) \\
23.9 \%\end{array}$ & $\begin{array}{c}(46) \\
42.2 \%\end{array}$ & $\begin{array}{c}(5) \\
4.6 \%\end{array}$ & $\begin{array}{c}(23) \\
21.1 \%\end{array}$ \\
\hline $\begin{array}{l}\text { 7- PD that I have participated in } \\
\text { helped me/us implement strategic } \\
\text { plans to improve the teaching and } \\
\text { learning of English at my school. }\end{array}$ & $\begin{array}{c}(9) \\
8.3 \%\end{array}$ & $\begin{array}{c}(25) \\
22.9 \%\end{array}$ & $\begin{array}{c}(47) \\
43.1 \%\end{array}$ & $\begin{array}{c}(5) \\
4.6 \%\end{array}$ & $\begin{array}{c}(23) \\
21.1 \%\end{array}$ \\
\hline $\begin{array}{l}\text { 8- Well-designed PD is likely to } \\
\text { have a positive and lasting impact } \\
\text { on my career goals. }\end{array}$ & $\begin{array}{c}(1) \\
0.9 \%\end{array}$ & $\begin{array}{c}(11) \\
10.1 \%\end{array}$ & $\begin{array}{c}(50) \\
45.9 \%\end{array}$ & $\begin{array}{c}(47) \\
43.1 \%\end{array}$ & None \\
\hline $\begin{array}{l}\text { 9- Well-designed PD is worth my } \\
\text { time to attend }\end{array}$ & $\begin{array}{c}(15) \\
13.8 \%\end{array}$ & $\begin{array}{c}(38) \\
34.9 \%\end{array}$ & $\begin{array}{c}(56) \\
51.4 \%\end{array}$ & None & None \\
\hline
\end{tabular}

As shown above in Table 3, item three aimed at asking the participants about their preparedness before their first teaching experience. The highest percentage of respondents $(36 \%)$ disagreed with the statement the university training and preparation they received before commencing their first English teaching position was sufficient to be an effective English teacher. A further 31\% of respondents strongly disagreed with this statement. Only $16 \%$ of respondents strongly agreed and $17 \%$ agreed with this statement. Therefore, data suggests that around $67 \%$ of trainee teachers believed they had insufficient preparation to be effective English teachers before commencing their first teaching post.

Items four to seven aimed at exploring the participants' experiences of PD and training. The data showed that $65.5 \%$ of those who participated in PD indicated that PD did not improve their knowledge or skills as an English teacher. On the other hand, only $34.5 \%$ of those who participated said that it improved their skills. For the responses to item seven, as can be seen in the table above, $55.9 \%$ of teachers who participated in PD indicated that PD did not increase their effectiveness in teaching and students' performance, while $44 \%$ who participated in PD found it increased their effectiveness.

For item six, the data reported that $59.3 \%$ of those who participated in PD thought that PD did not help them understand and utilize different measurements for assessment. However, $40.7 \%$ of those who participated in PD stated that PD helped them to use different measurements for assessment. Responses to item nine, indicated that $60.5 \%$ of the participants reported that PD did not help them implement strategic plans to improve the teaching and learning of English at their school. On the other hand, $40 \%$ of those who participated in PD stated that it helped them to use strategic plans in teaching and learning English.

Items eight and nine were about the value of PD. In item eight, $46 \%$ of respondents disagreed and $43 \%$ strongly disagreed with the statement Well-designed PD is likely to have a positive and lasting impact on my career goals, and only $1 \%$ strongly agreed. However, in item nine, with the slightly different wording Well-designed PD is worth my time to attend, no respondents strongly disagreed, though $51 \%$ disagreed. In contrast to item eight, 35\% agreed and 14\% strongly agreed. These results may be explained by the presence of poorly designed PD programs that lack stimulation and motivation and that were presented by ill-prepared trainers, all 
of which discouraged them from attending such events. It is also possible that teachers do not place enough value on continuing PD, and there could be further cultural factors and transportation issues that compound the problem.

\section{Methods and Duration of PD Opportunities}

The same Likert scale was used to determine what methods of PD Saudi English language teachers preferred, and the analysis focused on the percentage of respondents who indicated they were Very Interested in each item. The results indicated that the highest rated method for improving PD was Attending professional organization conferences for English teachers: $71 \%$. The highest rating of this statement could be due to the lack of availability of such organizations that help teachers attend conferences for training and enriching their knowledge and skills.

The next highest rated methods, in order of preference, were Development of professional learning communities with local colleagues: 55\%, One-day Workshops, Peer coaching/mentoring, and 2-3 day conferences: $53.2 \%, 53.2 \%$ and $52.3 \%$, respectively. However, the lowest interest was in online courses with or without collaborative meeting software with only $40.4 \%$ of respondents indicating they were Very Interested. Teachers rated the online courses as the least preferable because they wanted more opportunities that increased their authentic practice rather than online courses.

Table 4. Interest in Methods and Duration of PD Opportunities

\begin{tabular}{|c|c|c|c|c|}
\hline Statement & \begin{tabular}{|c|} 
Very \\
Interested
\end{tabular} & $\begin{array}{l}\text { Somewhat } \\
\text { Interested }\end{array}$ & Neutral & $\begin{array}{c}\text { Not } \\
\text { Interested }\end{array}$ \\
\hline $\begin{array}{l}\text { 10- Online courses with or without } \\
\text { collaborative meeting software. }\end{array}$ & $\begin{array}{c}(44) \\
40.4 \%\end{array}$ & $\begin{array}{c}(34) \\
31.2 \%\end{array}$ & $\begin{array}{c}(20) \\
18.3 \%\end{array}$ & $\begin{array}{c}(11) \\
10.1 \%\end{array}$ \\
\hline 11- Two-three day conferences. & $\begin{array}{c}(57) \\
52.3 \%\end{array}$ & $\begin{array}{c}(30) \\
27.5 \%\end{array}$ & $\begin{array}{l}(12) \\
11 \% \\
\end{array}$ & $\begin{array}{l}(10) \\
9.2 \% \\
\end{array}$ \\
\hline 12- one-day workshops & $\begin{array}{c}(58) \\
53.2 \%\end{array}$ & $\begin{array}{c}(34) \\
31.2 \%\end{array}$ & $\begin{array}{c}(7) \\
6.4 \%\end{array}$ & $\begin{array}{r}(10) \\
9.2 \%\end{array}$ \\
\hline $\begin{array}{l}\text { 13- Attending professional } \\
\text { organization conferences for English } \\
\text { teachers. }\end{array}$ & $\begin{array}{c}(77) \\
70.6 \%\end{array}$ & $\begin{array}{c}(19) \\
17.4 \%\end{array}$ & $\begin{array}{c}(6) \\
5.5 \%\end{array}$ & $\begin{array}{l}(7) \\
6.4 \%\end{array}$ \\
\hline 14- Peer coaching/mentoring. & $\begin{array}{c}(58) \\
53.2 \%\end{array}$ & $\begin{array}{c}(29) \\
26.6 \%\end{array}$ & $\begin{array}{c}(17) \\
15.6 \% \\
\end{array}$ & $\begin{array}{c}(5) \\
4.6 \% \\
\end{array}$ \\
\hline $\begin{array}{l}\text { 15- Development of professional } \\
\text { learning communities with local } \\
\text { colleagues. }\end{array}$ & $\begin{array}{l}(60) \\
55 \%\end{array}$ & $\begin{array}{c}(29) \\
26.6 \%\end{array}$ & $\begin{array}{c}(15) \\
13.8 \%\end{array}$ & $\begin{array}{c}(5) \\
4.6 \%\end{array}$ \\
\hline
\end{tabular}

\section{Interview Data Analysis}

A total of 109 of Saudi English language teachers, 10 of them volunteered to participate in the interview. The participants who were varied in their teaching experiences and preparation. Four of the ten teachers had extensive experience ranging from nine to twenty years. The rest were novice ranging from three years to six years' experience. Interestingly, all of them had a desire to teach differently than they were taught, and were very enthusiastic to improve. In order to explore the teachers' attitudes towards teaching English, they were asked to respond to 
four primary interview questions which center on the following topics: (1) pre-job training preparation, (2) availability of PD opportunities, (3) participation in inservice training and workshops and (4) the major obstacles which the teachers encountered while receiving PD.

(1) Pre-job training preparation

The essential inquiry about pre-job preparation was to understand the nature of teachers' pre-service training and professional development. This helped the researcher to get a glimpse of whether teachers were getting adequate pre-service training or not. The researcher also hoped to find any gaps that needed to be further studied and addressed for the creation of effective professional development modalities.

How do English teachers in Saudi Arabia currently perceive the amount and quality of English teaching preparation they received prior to their teaching position? The scope of responses reflected the preparation of new English teachers. Responses indicated that much effort in the development of quality teaching skills of current classroom teachers needs to be planned, designed and implemented. Future standards may call for students to develop knowledge and skills that teachers have not previously addressed. Other teachers further elaborated that education programs were weak when they attended university and did not prepare them adequately. Samar stated regarding her preparation:

"When I first stood in front of my students, I had no idea what to do! I went to private English institute to practice the language. I have never done presentations and no one assessed my speaking before. In the school, I observed other teachers while they teach."

Also, Abdullah described his experience:

"There was not enough preparation for English language teachers. What I was taught in college is completely different from reality. I was so shocked when I took my first job as a teacher in intermediate school. The experience was like a puzzle that I had to work out by myself. It was the most challenging task I have ever confronted."

Several teachers had similar experiences with pre-service training. Some teachers studied for four years as English majors (literature and linguistics) and at the end of the last year they took one methodology course and did a one-semester teaching practicum where they taught four 45 -minute periods per week. For other teachers, the first year at university was a preparatory year consisting of general courses and one course in English. The remaining three years of their major course of study in English were mostly linguistics and literature courses. Methodology courses were not part of the curriculum. Teachers during their study had never felt that the environment was conducive to learning and teaching the language which was supposed to include authentic practice full of enthusiasm and motivation for acquiring the foreign language.

Teachers who want to teach at universities, could be employed without receiving pre-service and prior training. If they want to be school teachers, after they graduate they need to take a one-year diploma consisting of educational courses 
taught in Arabic. At the end of their second semester, teachers are required to teach English at schools. Faisal described his experience as,

"The pre-service training and teacher education during the Bachelor degree was not enough to be adequately prepared. Although we graduated with high GPA because of memorizing the text we lacked adequate teacher preparation, opportunities for training to practice the English language."

(2) Availability of PD opportunities

The purpose of asking about the availability of PD opportunities was to gain a deeper understanding about PD and training for Saudi English language teachers as well as knowing what they need and what is missing in their training. Teachers in public schools indicated that they were offered limited opportunities such as meetings, or workshops offered twice annually. They viewed these PD opportunities as insufficient and not worthy of attending and considered them repetitive topics. Most of PD opportunities offered were lectures. In these PD opportunities, teachers did not find the support they wished for and found that even after the PD, they lacked effective training. There are some development programs done locally every year for all the teachers. These are like training sessions which are mostly lecturing or workshops by supervisors, periodic meetings, Ahmed described it as follows:

"There are some development programs done locally every year for all the teachers. These are like training sessions which are mostly lecturing or workshops by supervisors, periodic meetings. Honestly speaking, the development programs are not considered satisfying. New teachers often need more care and attention and their needs of topics of improvements are heard and respected and need to have qualified trainer."

(3) Participation in in-service training and workshops

The purpose of probing into the training of teachers was to gain an understanding of the perceived benefits they received from in-service training and PD opportunities. Teachers reported that they often participated in PD. However, it was difficult to benefit from the PD and in-service training in which they had participated due to the repetitive topics, providing useless information, not meeting teachers' needs, trainers were not qualified, not having alternative models for professional development, and not caring to choose appropriate times and locations. The interviewees stated that the Ministry of Education offers PD opportunities only one week per year, offering up to ten hours. However, teachers felt dissatisfied with their experience of PD where trainers need to vary in their PD models and topics to cater to teachers' needs. Teachers mentioned their dissatisfaction with their experience of PD. Reem and Omar described that as:

Most of PD opportunities offered were lectures or suggested strategies that could not be implemented within our school systems due to the lack of technology and short class periods (45 minutes)

Most participants stated their willingness to attend effective PD for the sake of being active practitioners. They reported their priority was ensuring the importance of attending such opportunities to mainly enhance their own skills and knowledge of the English language (i.e. their confidence in the subject) first and their teaching outcomes and students' performance second. Teachers stressed 
that it is important to consider choosing the time that best suits them and to select appropriate locations which would necessitate establishing centers in every city in Saudi Arabia, not only in the big cities, or enable online platforms for better PD opportunities. Teachers further elaborated that there is an urgent need to provide weekly sessions where teachers can meet and discuss the trends and challenges in TEFL. Then provide monthly PD workshops and topics that were based upon the weekly sessions. They also indicated that they needed this support since they are the ones who are responsible for teaching the content and are accountable for students' performance.

(4) Major obstacles encountered by the teachers

Investigating how teachers experienced PD training and figuring out the biggest obstacles they encountered was one of the primary purposes of the current study. These obstacles can be tackled through understanding teachers' needs and difficulties. Most of the teachers agreed they lacked support and a voice to choose and determine what they needed. Teachers also found that timing, location, and large group size were considered the most considerable difficulties to overcome. To access PD opportunities, teachers had to travel to big cities for PD sessions as Kingdom of Saudi Arabia Association of Language Teachers (KSAALT) conference that provides workshops and presentations every year. They suggested having training centers in each city would go a long way to facilitate attendance or at least enable it online platform. Samar indicated one of the obstacles of attending the PD is that

"usually such programs take place in morning sessions while teachers would have to work at these periods of time."

\section{Discussion}

This section discusses significant themes emerged from the findings stated earlier.

RQ1. How do English teachers in Saudi Arabia currently perceive the amount and quality of English teaching preparation they received prior to their teaching position?

The highest percentage of respondents disagreed with the statement the university training and preparation they received before commencing their first English teaching position was sufficient to be an effective English teacher. The data showed that $67 \%$ of trainee teachers reported having insufficient preparation to be effective English teachers before commencing their first teaching post. They believed their training and preparation to be ineffective. Inadequate preparation raises concerns and calls into question the effectiveness of teacher training programs in Saudi Arabian universities. Interview data revealed that majority of teachers obtained a Bachelor's degree without adequate preparedness in terms of knowledge, language proficiency and competence. Interviewees and the open-ended questions indicated that some teachers took one methodology course and had a practicum during the last semester of their study to visit schools three to four times during the semester and to teach lessons, while others graduated without methodology courses or a practicum.

For the development of best practices for EFL teachers, university preparation programs need to be planned, designed and implemented for enhancing quality teaching skills for these current classroom teachers. This is in alignment with Al- 
Hazmi (2003), Al-Khairy (2013), Al-Malihi (2015), Alrabai (2014), Alrashidi \& Phan (2015), and Al-Seghayer (2014a), who all emphasized that Saudi English language teachers graduate without theoretical background related to factors that affect second language learning and acquisition, and adequate training and competence. This in turn, results in unsuccessful learning EFL outcomes for students, i.e., unsatisfactory students' achievements of language proficiency and competency. Teaching methodology courses are offered and are given in the last semester and are no more than three credits, representing approximately only $10 \%$ of their coursework (Al-Seghayer, 2014a). Accordingly, this research strongly suggests that university programs need to be more comprehensive for effective and adequate preparation in the field of EFL. Further, preparation should be extensive, intensive and increased to nurture authentic practice and activities for the sake of successful learning language outcomes of proficiency skills and competency instead of weaknesses of teachers' education programs.

RQ2. What professional development opportunities for English teachers are available and being used in Saudi Arabia?

The questionnaire revealed that half of the teachers that responded to the questions did not have PD opportunities for continuing PD to broaden their knowledge/skills. This is confirmed by Zohairy's (2012) study that revealed $81 \%$ of teachers were not satisfied with current PD. The interviewees in the current study stated that professional development and training programs were offered once a year for ten hours during one-week period while others stated it was three days per year for 25 hours total. Further, the interviewees found repetitive topics and the trainers were inadequately trained and relied on mostly giving lectures, which mirrors how they are expected to teach their own students. Saudi English language teachers have willingness, even an eagerness, to see improvements in PD opportunities and training and want to understand and try alternative models that would empower them as well as address the weaknesses of teachers' education programs, and lack of teachers' role in PD programs.

All in all, these findings confirmed Al Malihi's (2015) study in which Saudi English language teachers responded negatively toward training programs with $59.09 \%$ of those educators reporting that they did not receive any training related to teaching theory and pedagogy. Saudi EFL teachers are not prepared with adequate pre-service preparation nor training programs, and not supported enough through in-service training programs to develop themselves professionally and be updated with sufficient training. Moreover, this research study supported Alsalahi's (2015) results that demonstrated teachers' dissatisfaction with PD and training due to the weaknesses of teachers' education programs and lack of teacher roles in PD programs. Despite these inadequacies in the system of EFL teacher preparation and ongoing development, teachers desire PD offerings that address their specific needs for PD and training in hopes of enacting change to cater to their needs and current inadequacies and challenges.

RQ3. How do Saudi English teachers perceive the effectiveness of their professional development?

Results of the questionnaire demonstrated that approximately half of the respondents did not take part in continuing PD activities' since the 
commencement of their teaching career. The majority of the teachers answered that they did not participate due to the timing, place and unsatisfactory experiences or repetitive topics and untrained trainers. There were statements regarding the effectiveness of PD and training that teachers could consider and respond to. With the statement related to the effectiveness of $P D$, teachers generally disagreed that they were receiving effective PD development. While it is true that data can be explained in different ways, it is conceivable, based on their responses, that teachers have no faith in current PD programs, that there are very few PD programs to engage with that would enrich their career goals, and that is an absence of PD training experiences altogether.

Further, one can conclude from the collected data that teachers' dissatisfaction with PD is due to lack of PD trainers' professional competence, the quality of PD learning that teachers' experience, and ultimately the students' outcomes in terms of knowledge and skills. Teachers have not engaged in the given topics through PD and have found that the training does not match their needs. Interestingly, more than half the respondents pointed out that attending professional training is not worth their time and effort. The data confirmed dissatisfaction of not having effective PD opportunities among teachers, and this aligns with the literature review results.

Overall, this is a problem for EFL teacher due to the lack of opportunities to develop, teachers cannot acquire the knowledge/skills needed to enact improvements and strategic planning for EFL. The data further suggests that the quality of professional interaction that teachers take part in and current PD activities do not ensure teacher learning sufficient to improve the knowledge/skills of teachers which in turn impacts improvements in student learning and achievement.

Most of the participants in the interview and open-ended questions stated their eagerness to be active practitioners for the sake of having effective professional development and training. They reported the importance of attending to such PD opportunities that would enhance their own skills in subject and language knowledge first to raise their self-confidence and they viewed their teaching outcomes and students' performance as secondary. Teachers need a voice to be involved in choosing the topics, appropriate times, and locations that suits their needs and circumstances. They need support since they are the ones who are responsible for teaching the content and are accountable for students' performance.

According to the models of PD which Saudi English teachers prefer, the results indicated that teachers rated attending professional organization conferences for English teachers the highest, at 77 (71\%). This is followed by the development of professional learning communities with local colleagues 60 (55\%). One day workshops, peer coaching/mentoring, and 2-3 day conferences were 58 (53\%), 58 (53\%), and 57 (52\%), respectively. The interviews and open-ended questions revealed teachers' opinions that opportunities for PD and training such as meetings, sessions or 
workshops were limited to the extent that their teaching practice was negatively impacted.

Interviewees emphasized the need for PD that include authentic practice, active training and learning by doing. Further, it was emphasized that teachers' work schedules need to be considered as well as more appropriate locations. Teachers agreed on the utility of weekly sessions to determine their challenges and needs and to allow professional discussions between teachers to exchange ideas. This should be followed up with monthly workshops, PD and training based on what on the suggested upon topics from the weekly sessions. The ideal time should be over the weekend, and organization or centers should be available in each city in Saudi Arabia or even enable online PD sessions.

\section{Conclusion}

This research aimed at exploring professional development in the teaching and learning of the English language for teachers in Saudi Arabia to support the goals of English language acquisition for Saudi English language learners. The purpose of this research was to assess teachers' views regarding the current available of professional development and training of Saudi English teachers as well as teachers' preferences for new and alternative models and durations of professional development. The study found a lack of provision and opportunity to undertake PD for English language teachers. The findings suggest there is a need for an organized body for maintaining PD opportunities and the quality of PD leaders. Expectations of the PD leader must be clearly stated and quantifiable in terms of the identification of teachers' needs, PD planning and evaluation, what resources are available to support the role of teachers to benefit, and for the government to achieve its strategic goals. The research found that schools have varied understandings of both the nature and the value of PD. The implication of this finding is that PD would be of benefit if it were flexible enough to allow teachers to demonstrate learning in both traditional and non-traditional ways through courses and portfolio work.

To accomplish major changes in teacher satisfaction, the quality of English teacher preparation and ongoing training in Saudi Arabia must change. Attention must be paid to the teachers as they are the key factor in the teaching and learning process. The Ministry of Education needs to provide trainers and training programs that incorporate more interactive approaches, materials testing, and professional development for teachers whose opinions suggest their involvement in this training is long overdue. Thus, learning must occur after actual experiences and activities (Dewey,1938). This study has implications for further practice in relation to how the results will impact further decision making regarding the provision of PD. This research has provided a better understanding of PD needs within the Saudi context. However, further investigation in the current research area is recommended. Additionally, new systems need to be instituted to provide: (1) appropriate pre-service education for English Language Teaching programs,

(2) localized, appropriate professional development and training for teachers. The research on the professional development (PD) needs of English teachers in Saudi Arabia offers a grounded approach in looking at teachers' preparation, practice, 
and previous PD with the goal of uplifting and inspiring teachers through PD. The primary concern is with the quality of PD as well as PD's impact on the quality of teaching in the classroom.

\section{Recommendations and future research}

Professional development needs-analysis of English Teachers in the Saudi Arabia led to the following recommendations for future action: (1) Ministry of Education should do more to foster PD expertise and training of PD presenters. (2) Teachers need to be assessed before attending any model of PD to assess teachers' level and competency. (3) PD programs should start from the bottom up instead of top down where teachers can choose the topic they are interested in.

In addition to what has been mentioned, further research is required to increase understanding of how professional development can be enhanced among teachers and leaders. Studies that analyze and retrieve feedback from the designed and suggested programs of PD in Saudi Arabia may help researchers understand the effectiveness of long-term PD. It is hoped that this study will contribute in diagnosing the weaknesses in professional development in Saudi Arabia and motivate policy makers to make changes and implement new strategies to develop teaching professionals. The researcher suggests that PD organizers and trainers should gauge the readiness and interests of the specific group of teachers with whom they will be working prior to implementing PD workshops. This could be done through a survey to tailor effective PD and training for teachers and ascertain teachers' previous knowledge, skills, competencies and language proficiency. This measurement will assist language teachers to be well-prepared linguistically and instructionally.

\section{References}

Ahmad, A. M. (2014). Kumaravadivelu's framework as a basis for improving English language teaching in Saudi Arabia: Opportunities and challenges. English Language Teaching, 7(4). https://doi.org/10.5539/elt.v7n4p96

Al-Hazmi, S. (2003). EFL teacher preparation programs in Saudi Arabia: Trends and challenges. TESOL Quarterly, 37(2), 341-344. https://doi.org/10.2307/3588509

Al-Khairy, M. H. (2013). English as a foreign language learning demotivational factors as perceived by Saudi undergraduates. European Scientific Journal, 9(32).

Al-Malihi, J. F. (2015). Saudi EFL teachers' readiness and perceptions of young learners teaching at elementary schools. English Language Teaching, 8(2), 86. https:// doi.org/10.5539/elt.v8n2p86

Alotaibi, G. N. (2014). Causes of private tutoring in English: Perspectives of Saudi secondary school students and their parents. International Conference on Education and Language 1, 60-65.

Alrashidi, O., \& Phan, H. (2015). Education context and English teaching and learning in the Kingdom of Saudi Arabia: An overview. English Language Teaching, 8(5), 33. https://doi.org/10.5539/elt.v8n5p33

Alrabai, F. (2014). Motivational practices in English as a foreign language classes in Saudi Arabia: Teachers beliefs and learners' perceptions. Arab World English Journal, 5(1), 224-246. 
Alrabai, F. (2016). Factors Underlying Low Achievement of Saudi EFL Learners. International Journal of English Linguistics, 6(3), 21. https://doi.org/10.5539/ijel.v6n3p21

Alsalahi, S. M. (2015). Stages of teacher's professionalism: How Are English Language Teachers Engaged? Theory and Practice in language studies, 5(4), 671. https://doi.org/10.17507/tpls.0504.01

Al-Seghayer, K. S. (2014a). The actuality, inefficiency, and needs of EFL teacherpreparation programs in Saudi Arabia. International Journal of Applied Linguistics and English Literature, 3(1), 143-151. https://doi.org/10.7575/aiac.ijalel.v.3n.1p.143

Al-Seghayer, K. S. (2014b). The four most common constraints affecting English teaching in Saudi Arabia. International Journal of English Linguistics, 4(5), 17. https://doi.org/10.5539/ijel.v4n5p17

Al-Seghayer, K. S. (2015). Salient key features of actual English instructional practices in Saudi Arabia. English Language Teaching, 8(6), 89. https://doi.org/10.5539/elt.v8n6p89

Badia, M. H. (2015). Teacher Evaluation as a Tool for Professional Development: A Case of Saudi Arabia. Advances in Language and Literary Studies, 6(5), 97-103. https://doi.org/10.7575/aiac.alls.v.6n.5p.97

Craft, A. (1996). Continuing Professional Development: A Practical Guide for Teachers and Schools. London: Routledge. https:// doi.org/10.4324/9780203420041

Cross, D. (1995). Language teacher preparation in developing countries: structuring preservice teacher training programs, English Teaching Forum, 33(4), 35.

Crawford, L., Schmeister, M., \& Biggs, A. (2008). Impact of intensive professional development on teachers' use of sheltered instruction with students who are English language learners. Journal of In-service Education, 34(3), 327342. https://doi.org/10.1080/13674580801950816

Creswell, J. W. (2012). Educational Research: Planning, Conducting, and Evaluating Quantitative and Qualitative Research, (4 ${ }^{\text {th }}$ edn). Upper Saddle River, NJ: Merrill Prentice-Hall.

Day, C. (1999). Professional development and reflective practice: purposes, processes and partnerships. Pedagogy, Culture and Society, 7(2), 221-233. https://doi.org/10.1080/14681366.1999.11090864

Dewey, J. (1938). Experience and education. New York: Macmillan.

DiCicco-Bloom, B., \& Crabtree, B. F. (2006). The qualitative research interview. Medical education, 40(4), 314-321. https://doi.org/10.1111/j.1365-2929.2006.02418.x

DuFour, R., \& Eaker, R. (1998). Professional learning communities at work: Best practices for enhancing student achievement. Bloomington, IN: Solution Tree Press.

Igawa, K. (2002). The effects of in-service training on teachers' explanation of lexical items in Japanese high school classrooms. (Doctoral Dissertation). Temple University.

Igawa, K. (2008). Professional development needs of EFL teachers practicing in Japan and Korea. International Buddhist University Bulletin, 45, 431-455.

Oudah, F., \& Altalhab, S., (2018). Saudi EFL Teaching Training Programmes: Teachers' Perceptions and Needs. Theory and Practice in Language Studies, 8(11), p.1407. https://doi.org/10.17507/tpls.0811.04

Preparatory Year English Program: The Future and beyond: student, teacher, pedagogy and curricular issues. (pp. 162-183). Madinah, Taibah University.

Putnam, R. T., \& Borko, H. (2000). What do new views of knowledge and thinking have to say about research on teacher learning?. Educational researcher, 29(1), 4-15. https://doi.org/10.3102/0013189x029001004 
Rahman, M., \& Alhaisoni, E. (2013). 'Teaching English in Saudi Arabia: prospects and challenges'. Academic Research International, 4(1), 112-118.

Richards, J. C., \& Farrell, T. S. C. (2005). Professional development for language teachers: Strategies for teacher learning. New York, NY: Cambridge University Press.

Richards, J. C., \& Rodgers, T. S. (2001). Approaches and methods in language teaching. Cambridge, UK: Cambridge University Press. https://doi.org/10.1017/cbo9780511667305

Rubin, H. J., \& Rubin, I. S. (2005). Qualitative interviewing: The art of hearing data. Thousand Oaks, CA: Sage. https://doi.org/10.4135/9781452226651

Sparks, D. (2002). Designing Powerful Professional Development for Teachers and Principals. National Staff Development Council.

Talbert, J. E., \& McLaughlin, M. W. (1994). Teacher professionalism in local school contexts. American journal of education, 123-153. https:/ / doi.org/10.1086/444062

Zohairy, S. A. (2012). Professional Development Challenges and Possible Solutions in the Saudi Context. 